\title{
Perencanaan Lanskap Kawasan Pura Dalem Mutering Jagat Kesiman
}

\author{
I Kadek Hendra Krisdiandinata ${ }^{1}$, I Gusti Agung Ayu Rai Asmiwyati1* , I Nyoman Gede Astawa ${ }^{2}$ \\ 1. Program Studi Arsitektur Lanskap, Fakultas Pertanian, Universitas Udayana, Indonesia 80232 \\ 2. Program Studi Agroekoteknologi, Fakultas Pertanian, Universitas Udayana, Indonesia 80232
}

*E-mail: asmiwyati@unud.ac.id

\begin{abstract}
The Landscape Planning of The Area in The Pura Dalem Mutering Jagat Kesiman. The sanctum area is an area around a temple that needs to be kept sacred within a certain radius within the Parisada Hindu Dharma Indonesia Central Decree, concerning Bhisama Kesucian Pura. Pura Dalem Mutering Jagat Kesiman (PDMJK) as Khayangan Tiga temple in Denpasar-Bali has a sacred radius area, namely Apenyengker. Some obstacles have interfered with the activities and sanctity of the temple that will need to be overcome, to be able to create a more sanctum area. The primary objective of the research was to plan the ideal sanctum and also to identify the biophysical and socio-cultural aspects. The method used was the survey method by considering the value of abiotic - biotic (biophysical) and culture (socio-cultural). At the same time, the stages were data inventory, analysis, synthesis, basic concepts, concept development, and planning stages. The data analysis and synthesis were carried out from the socio-cultural and biophysical aspects of qualitative descriptive and quantitative spatial by using the MCDA (multicriteria decision analysis) method. From the research results, there was a steep slope of land into a danger signal which concludes that the area needs to be conserved. The poor spatial planning, especially the temporary stall and parking area, was still unorganized. The spatial planning concept resulted in 3 (three) zones, namely the sacred zone, the conservation buffer zone, and the profane zone. The plan was to use the vegetation concept to vegetate the area with Balinese ceremony plants with conservation value. The idea of circulation was the foundation for the circulation of pedestrians and transportation circulation. The development of the facilities was needed to create new space and support the activities at PDMJK such as park benches, gates, canteen and pedestrians.
\end{abstract}

\section{Keywords: Conservation, Holy Place Area, Landscape Planning}

\section{Pendahuluan}

Kawasan tempat suci yang diatur dalam Perda Provinsi Bali nomor 16 tahun 2009 tentang RTRW Provinsi Bali pada BAB I nomor 41 menyatakan bahwa kawasan tempat suci adalah kawasan yang disekitar pura yang perlu dijaga kesucian dalam radius tertentu. Pura Dalem Mutering Jagat Kesiman (PDMJK) termasuk dalam Pura Khayangan Tiga yang radius kawasan sucinya adalah kawasan pura yang termasuk area luar pura, yang sudah mendapat proses penyucian dengan upacara serta didukung secara administrasi legal dan fisik. Kawasan PDMJK perlu dipertahankan dan dijaga serta pengembangannya perlu tetap mendukung fungsinya sebagai kawasan suci (Ardana, 1999).

Pura Dalem Mutering Jagat Kesiman (PDMJK) saat ini memiliki area dalam pura dan area luar yang terdiri dari area parkir, area pedagang (pada kondisi tertentu), dan area jalan. Penataan ruang di kawasan PDMJK belum tertata dengan baik dan belum jelas pola ruang sesuai kepentingan pura. Area parkir belum ditata dengan maksimal sehingga menghambat dan mengganggu sirkulasi masyarakat pada saat menuju pura, terutama pada saat piodalan di PDMJK. Aktivitas pedagang lokal pada saat piodalan (perayaan hari jadi tempat suci) juga belum ditata dengan baik, sehingga mengganggu sirkulasi masyarakat menuju area pura. Pada hari biasa dengan keadaan kawasan pura yang belum tertata dengan baik, berpotensi terjadinya tindakan yang melanggar aturan atau norma agama seperti berkelahi, berburu, dan kegiatan lain yang berpotensi melanggar norma agama yang dapat mengurangi kesucian pura. Kawasan PDMJK dikembangkan dan direncanakan sesuai fungsi PDMJK sebagai kawasan suci. Kawasan PDMJK dikembangkan berdasarkan pemanfaatan potensi dan alternatif solusi kendala dari karakter biofisik, dan sosial budaya masyarakat setempat dikawasan PDMJK. 


\section{$2 \quad$ Metode}

\subsection{Lokasi Penelitian}

Penelitian ini dilakukan di kawasan Pura Dalem Mutering Jagat Kesiman, Denpasar Timur, Denpasar. (Gambar 1.) Ukuran luas lokasi penelitian ini 2,87 Ha. Adapun batas-batas kawasan lokasi penelitian:

- Batas Utara

- Batas Timur

- Batas Barat

- Batas Selatan
: Jalan Raya Wr. Supratman.

: Rumah Warga, Tanah Pemprov Bali.

: Aliran Sungai Tukad Ayung.

: Rumah Warga.

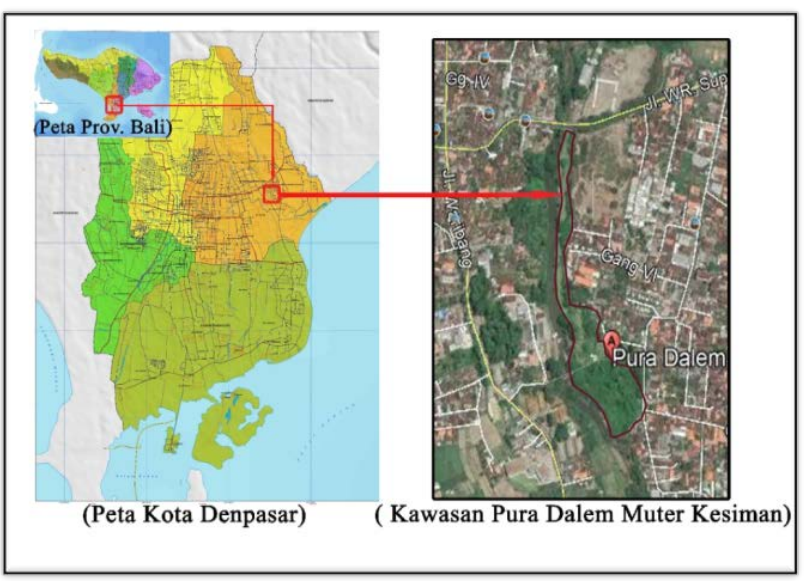

Gambar 1. Peta Lokasi Penelitian PDMJK

\section{$2.2 \quad$ Alat}

Alat Yang digunakan yaitu kamera Handphone, alat tulis, laptop, untuk perangkat lunak yang digunakan yaitu Google Earth, Auto Cad 2013, Adobe Photoshop Cs 6, ArcGis, MS Word, MS Excel.

\subsection{Metode Penelitian}

Metode survei digunakan pada penelitian ini, dengan mempertimbangkan perencanaan abiotikbiotik (biofisik) dan sosial budaya (Ahern, 2014). Adapun tahapannya yaitu, inventarisasi data, analisis, sintesis, konsep dasar, pengembangan konsep, dan tahap perencanaan. Pengambilan data melalui proses observasi, wawancara, kuesioner, dan studi pustaka.

Data yang digunakan yaitu data dari aspek biofisik dan sosial budaya dari tapak. Pengolahan data melalui proses analisis dan sintesis yang mempertimbangan aspek bahaya, potensi, dan kendala pada tapak. Penentuan zona ruang menerapkan metode MCDA (multicriteria decision analisys) yaitu metode analisis dengan menggabungkan data multikriteria pada tapak untuk mendapatkan alternatif keputusan, dengan teknik scoring dan pembobotan terhadap data spasial dari aspek aktivitas sosial budaya, data vegetasi, dan kemiringan lahan yang dilakukan dengan teknik overlay pada pengaplikasian Geographic Information System (GIS).

\section{$3 \quad$ Hasil dan Pembahasan \\ 3.1 Inventarisasi dan analisis data}

3.1.1 Data dan Analisis Sosial budaya

Aspek sosial budaya diidentifikasi berdasarkan penataan ruang dan aktivitas di kawasan PDMJK. Penataan ruang pada kawasan PDMJK dibagi dua area yaitu area dalam pura dan area luar pura. (1) Penataan ruang di area dalam PDMJK sudah menerapkan konsep tata ruang ajaran Agama Hindul tata ruang tradisonal Bali yaitu konsep Tri Mandala. Konsep Tri Mandala pada area dalam PDMJK berorientasi pada sumbu matahari. Sumbu matahari untuk menentukan batas ruang, pola ruang dan aktivitas manusia. Penataan ruang paling timur adalah "Utama Mandala" atau jeroan, bagian tengah "Madya Mandala" atau jaba tengah dan yang barat adalah "Nista Mandala" atau jaba sisi (Raharja, 1993). (2) Area luar PDMJK terdiri dari: hutan, ruang 
kosong, dan area jalan berupa pedestrian menuju pura. Area hutan memiliki fungsi penting dalam kawasan ini. Vegetasi yang tumbuh di area hutan sering dimanfaatkan oleh masyarakat sebagai bahan sarana upakara untuk piodalan. Fungsi lain, hutan ini yaitu untuk pelestarian sumber daya alam PDMJK. Ruang kosong dimanfaatkan sebagai tempat parkir oleh masyarakat pada saat piodalan berlangsung dan dimanfaatkan sebagai tempat berdagang. Area dagang dan parkir yang berdekatan dengan area dalam pura, berpotensi mengganggu aktivitas sakral di dalam pura. Oleh karena itu perlu penataan ruang yang sesuai dan tidak mengganggu aktivitas sakral pura dan tidak mengganggu aksesibilitas pura.

Aktivitas pada PDMJK dijabarkan berdasarkan kegunaan ruang pada kawasan pura. Aktivitas yang terjadi di area dalam pura yaitu aktivitas sakral seperti: sembahyang, kegiatan ritual keagamaan yang bersifat paling suci dilakukan pada area Utama Mandala, kegiatan sosial tradisi seperti rapat dan tajen suryak dilaksanakan di area Madya Mandala, dan pada Nista Mandala kegiatan yang dilakukan yaitu untuk menyiapkan sarana odalan, seperti membuat penjor dan banten.

Aktivitas di luar pura bersifat sosial dan tidak terlalu bersifat religi atau profan, namun demikian tetap diperlukan untuk mendukung pelaksanaan aktivitas persembahyangan masyarakat. Aktivitas dagang dan parkir bersifat temporary khususnya pada saat odalan. Aktivitas ini mengganggu sirkulasi masyarakat untuk masuk/keluar pura karena letaknya berdekatan dengan area dalam pura. Selain itu, kegiatan berdagang ini berintensitas tinggi yang bisa mengganggu aktivitas sakral di dalam pura sehingga diperlukan penataan. Masyarakat juga memanfaatkan area luar pura untuk aktivitas sosial. Aktivitas yang dilakukan masyarakat berdasarkan hasil kuesioner yaitu bersantai dan beristirahat $(53,2 \%)$, memancing $(30 \%)$, bersih - bersih $(6,6 \%)$ dan kegiatan lain (3,3\%) yaitu berolahraga, photoshoot, dan tidak ada aktivitas. Berdasarkan hasil kuesioner aktivitas yang paling relevan difasilitasi atau direncanakan yang mendukung untuk kawasan suci, yaitu aktivitas bersantai dan istirahat, karena presentasenya paling banyak, juga paling dibutuhkan oleh masyarakat. Diagram kuesioner aktivitas PDMJK dapat diamati pada Gambar 2.

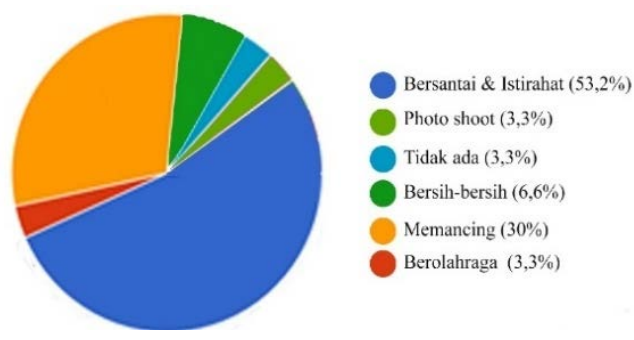

Gambar 2. Diagram Kuesioner Aktivitas PDMJK

Aktivitas yang terjadi yaitu masyarakat sekitar pura kurang peduli terhadap kelestarian SDA yang terdapat di kawasan PDMJK. Hasil wawancara aktivitas eksploitasi sering dilakukan oleh masyarakat, salah satunya aktivitas berburu burung pada kawasan PDMJK. Aktivitas ini sering dijumpai di area hutan. Tentunya hal ini melanggar norma agama dan dapat menodai kesucian pura. Berdasarkan wawancara aktivitas di area hutan yang dijijkan hanya untuk mencari tanaman yang dibutuhkan untuk sarana upakara.

Berdasarkan analisis dan identifikasi terhadap aktivitas sosial budaya di PDMJK dapat dijabarkan menjadi: 1) Area sakral, aktivitas yang dominan secara keseluruhan di area pura, yaitu aktivitas sakral dan religi. 2) Area pasif, area pasif merupakan area hutan yang jarang terdapat aktivitas. Adapun aktivitas yang dilakukan di area ini untuk mencari tanaman yang dibutuhkan sebagai sarana upakara. Area ini memiliki fungsi penting bagi PDMJK, salah satunya sebagai penyedia tanaman upakara. 3) Area profan non intensif, area ini sebagai peralihan dari aktivitas profan/sosial bernilai intensif yang dapat mengganggu aktivitas sakral. Hasil analisis bahwa perlu area peralihan yang difungsikan untuk membatasi aktivitas profan yang intensitasnya tinggi seperti aktivitas dagang dan parkir, dengan tujuan tidak mengganggu aktivitas sakral di dalam pura. 4) Area profan intensif, area ini terdiri dari ruang kosong yang terdapat di kawasan PDMJK, berdasarkan analisis ruang ini bisa dimanfaatkan sebagai aktivitas profan yang mendukung kawasan PDMJK seperti dimanfaatkan untuk area dagang dan parkir. Peta aktivitas dapat diamati pada Gambar 3. 


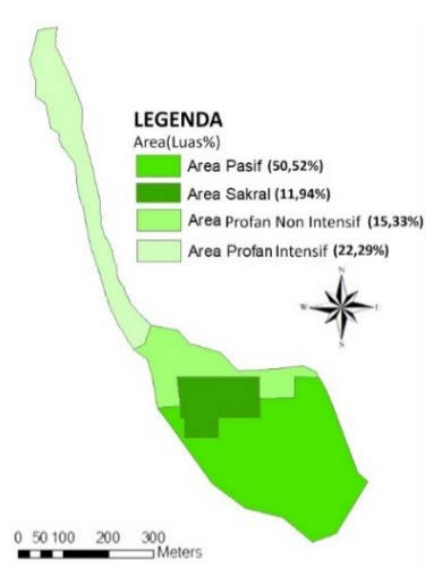

Gambar 3. Peta Deliniasi Aktivitas Sosial Budaya

\subsubsection{Data dan Analisis Biofisik}

Jenis tanah yang terdapat pada kawasan sekitaran PDMJK yaitu jenis mollisol (Kusmawati, 2016). Tanah mollisol merupakan tanah yang memiliki tingkat kesuburan yang tinggi dikarenakan akumulasi bahan organik yang kaya dengan kandungan $\mathrm{Ca}$ dan $\mathrm{Mg}$ dari hasil dekomposisi akar rumput - rumputan (Fiantis, 2015). Sehingga berpotensi untuk penanaman segala jenis vegetasi.

Sumber air yang terdapat pada PDMJK ada dua yaitu yang pertama aliran Sungai Ayung yang berposisi berdekatan dengan area PDMJK, dan sumur suci yang berada di area jaba tengah pura. Kondisi Sungai Ayung yang berdampingan dengan area PDMJK memberi daya tarik dari segi visual serta sumber daya alamnya yang harus dijaga dan dilestarikan, kondisi ini berpotensi untuk mendukung kawasan PDMJK sebagai kawasan tempat suci.

Beragam jenis vegetasi yang terdapat di kawasan PDMJK, vegetasi yang tumbuh di area luar PDMJK didominasi oleh pohon dan non pohon berupa semak liar dan groundcover. Bagian dalam PDMJK terdapat vegetasi yang didominasi non pohon berupa semak dan groundcover. Vegetasi yang mempunyai fungsi sebagai tanaman upakara dipertahankan untuk mendukung sarana prasarana keagamaan. Vegetasi dengan karakteristik pohon di area luar dipertahankan karena dapat memberikan nilai ekologis untuk kawasan PDMJK, yaitu nilai ekologis sebagai fungsi iklim mikro, pelestarian fauna dan sebagai penahan erosi. Kondisi semak liar yang tidak tertata menjadi pertimbangan penataan vegetasi di PDMJK perlu direncanakan dengan tujuan menambah nilai keindahan di kawasan PDMJK. Sebaran vegetasi pohon mendominasi di kawasan PDMJK dengan $57,14 \%$, dan sebaran vegetasi non pohon dengan $42,86 \%$. Berikut peta vegetasi PDMJK dapat diamati pada Gambar 4.

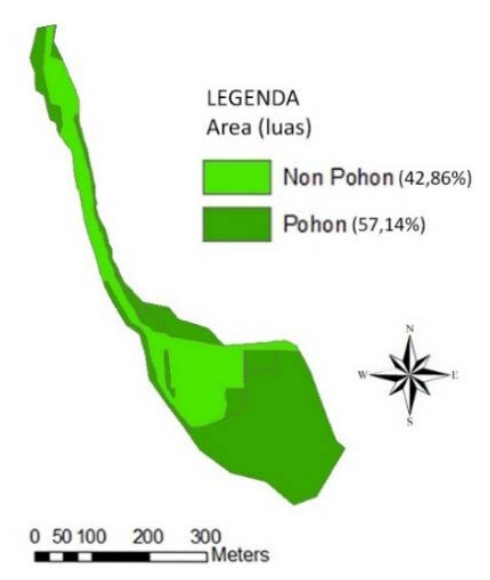

Gambar 4. Peta Dominasi Vegetasi

Kondisi topografi di kawasan PDMJK berdasarkan hasil observasi yaitu kemiringan lahan yang curam terdapat pada kawasan luar PDMJK yaitu pada perbatasan pura dengan tanah Pemprov Bali dan di daerah pinggir sungai, kemiringan lahannya mencapai $60 \%-83 \%$. Kemiringan lahan agak curam terdapat di area hutan dekat pinggir sungai dengan kemiringan 19\% - 25\%. Kemiringan lahan landai di kawasan PDMJK 
terdapat pada area jalan dan hutan atau teba pura yaitu sekitar $10 \%-11 \%$. Kemiringan lahan datar mendominasi di kawasan PDMJK yaitu sekitar 0\% - $8 \%$ yang terdapat di area pura sendiri dan kawasan luar pura. Kemiringan lahan yang sangat curam sangat berbahaya dan memberi pengaruh buruk bagi tapak PDMJK. Disamping membahayakan bagi pengguna atau masyarakat, jika tidak diantisipasi dapat menyebabkan erosi. Peta kemiringan lahan dapat diamati pada Gambar 5.

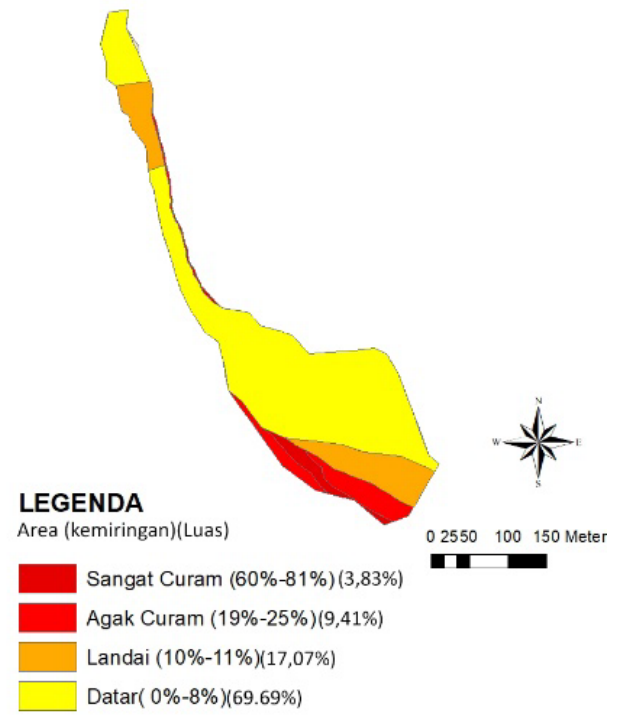

Gambar 5. Peta Kemiringan Lahan PDMJK

Berdasarkan tabulasi data, dapat dijabarkan pada peta yaitu terdapat 4 (empat) ketegori kemiringan lahan, yaitu datar, landai, agak curam dan sangat curam. Area kemiringan yang agak curam dan sangat curam menjadi danger signal atau bahaya karena bisa menyebabkan erosi. Kemiringan lahan yang agak curam dan sangat curam dapat direncanakan sebagai area konservasi. Area kemiringan lahan yang datar dan landai masih bisa dimanfaatkan untuk pengembangan ruang dan aktivitas di kawasan PDMJK.

Akses masuk menuju Pura Dalem Muter Jagat Kesiman (PDMJK) ada dua yaitu, akses yang melalui Jalan WR. Supratman dan akses yang melalui Jalan Soka. Sirkulasi kendaraan yaitu sirkulasi linear. Sirkulasi kendaraan untuk roda empat hanya bisa melalui akses dari utara karena memiliki area parkir yang memadai untuk kendaraan roda empat. Sirkulasi kendaraan roda dua bisa menggunakan kedua jalur. Sirkulasi manusia bisa mengakses seluruh bagian tapak. Kendala sirkulasi terutama sirkulasi antara kendaraan dengan pejalan kaki yaitu pada saat odalan, berdasarkan pengamatan yang dilakukan pada saat odalan dimana parkir dari sepeda motor menghalangi akses pejalan kaki atau pengguna untuk masuk menuju pura, yang menyebabkan hambatan untuk pejalan kaki. Kendala yang lain yaitu akses masuk menuju PDMJK dari Jalan Soka masih terbuka. Tidak adanya gate atau gerbang masuk dari area tersebut memberikan kebebasan bagi masyarakat atau pengguna untuk masuk ke kawasan PDMJK. Sehingga aktivitas yang dilakukan di kawasan PDMJK tidak bisa dikontrol.

\subsection{Sintesis}

Area dalam pura tidak dikembangkan lagi baik secara tata ruang dan aktivitas karena sudah menerapkan konsep Tri Mandala dan penggunan ruang sakral. Hasil analisis perlu direncakanan area buffer yang difungsikan untuk menghindari kegiatan yang ramai, berisik atau intensif seperti aktivitas dagang di dekat area dalam pura, yang dapat mengganggu aktivitas sakral/religi di dalam pura. Memberikan sosialisasi, larangan terhadap masyarakat, dengan harapan masyarakat paham akan kelestarian sumber daya alam PDMJK sebagai kawasan suci sehingga tidak terjadi kegiatan eksploitasi. Selain itu meningkatkan keamanan dari segi fisik terutama terhadap akses-akses masuk kawasan yang belum tekontrol dengan baik.

Tanah mollisol memiliki tingkat kesuburan yang tinggi sehingga bagus dimanfaatkan untuk perencanaan vegetasi di PDMJK. Tanaman upakara akan dikonservasi di daerah hutan dengan tujuan untuk kebutuhan upakara atau banten yang dibutuhkan masyarakat. Selain itu juga merencanakan tanaman yang memiliki fungsi ekologis yaitu untuk mencegah erosi, tanaman eksisting yang sudah berkarakterisitik pohon 
besar sebisa mungkin untuk dipertahankan karena berpotensi untuk menciptakan iklim mikro di kawasan PDMJK. Area yang memiliki kemiringan curam direncanakan untuk dikonservasi dengan merencanakan tanaman yang memiliki fungsi untuk mencegah erosi. Menerapkan metode vegetatif yaitu dengan merencanakan tanaman penutup tanah.

Kendala yang terjadi pada aksesibilitas di kawasan PDMJK yaitu kondisi parkir yang belum tertata dengan jelas sehingga mengganggu akses masuk menuju pura. Penataan parkir yang baik sehingga tidak mengganggu dari akses masuk menuju pura. Kendala lain yaitu akses masuk menuju PDMJK dari Jalan Soka masih terbuka atau belum terdapat gerbang sebagai fungsi kontrol di PDMJK. Kondisi tersebut menjadi pertimbangan perlu ditambahnya fasilitas fisik berupa gerbang atau gapura candi sebagai fungsi keamanan dari kawasan PDMJK khususnya dari akses masuk Jalan Soka. Merencanakan fasilitas pedestrian agar pengguna pejalan kaki bisa dikondisi yang aman dan nyaman serta tidak terganggu dari akses transportasi.

Pada aktivitas sosial budaya, nilai bobotnya yaitu 60 dan skor tertinggi yaitu pada sub data aktivitas sakral. Nilai bobot dan skor pada data aktivitas sosial budaya yang paling tinggi dikarenakan aspek ini memiliki nilai terpenting dalam perencanaan kawasan suci PDMJK. Pada data vegetasi, nilai bobotnya yaitu 25 dan skor tertinggi yaitu pada dominasi pohon. Dominasi pohon dipertimbangkan untuk mengetahui tutupan lahan yang mendominasi di kawasan PDMJK sehingga area tersebut dapat dipertimbangkan untuk dikonservasi. Pada data kemiringan lahan nilai bobotnya yaitu 15 dengan skor tertinggi yaitu kemiringan lahan yang sangat curam. Nilai skor kemiringan lahan berdasarkan surat Keputusan Menteri Pertanian No. 837/KPTS/UM/11/1980. Parameter kemiringan lahan untuk mengetahui area yang berpotensi bahaya karena kemiringan lahan yang curam di kawasan PDMJK, sehingga dapat dipertimbangkan untuk dikonservasi.

Overlay dilakukan terhadap data yang dianalisis dengan menggabungkan hasil scoring dan pembobotan pada data aktivitas sosial budaya, vegetasi, dan kemiringan lahan. Hasil akhir berupa nillai total yang dijadikan dasar keputusan dalam penentuan ruang pada kawasan PDMJK. Hasil scoring, pembobotan dan overlay dapat diamati pada Tabel 1.

Tabel 1. Hasil Overlay Data Aktivitas Sosial Budaya, Vegetasi, dan Kemiringan Lahan

\begin{tabular}{llllllll}
\hline $\begin{array}{l}\text { Aktivitas } \\
\text { Sosial Budaya }\end{array}$ & $\begin{array}{l}\text { Total } \\
\text { Skor }\end{array}$ & Vegetasi & $\begin{array}{l}\text { Total } \\
\text { Skor }\end{array}$ & $\begin{array}{l}\text { Kemiringan } \\
\text { Lahan }\end{array}$ & $\begin{array}{l}\text { Total } \\
\text { Skor }\end{array}$ & $\begin{array}{l}\text { Jumlah } \\
\text { Total } \\
\text { Skor }\end{array}$ & Zona \\
\hline Profan & 60 & Non Pohon & 25 & Datar & 15 & 100 & Zona Profan \\
Profan & 60 & Non Pohon & 25 & Landai & 30 & 115 & Zona Profan \\
Profan & 60 & Pohon & 50 & Datar & 15 & 125 & Zona Profan \\
Profan & 60 & Non Pohon & 25 & Agak Curam & 45 & 130 & Zona Profan \\
Profan & 60 & Pohon & 25 & Landai & 30 & 140 & Zona Profan \\
Profan & 60 & Pohon & 50 & Agak Curam & 45 & 155 & Zona Profan \\
Area Pasif & 120 & Non Pohon & 25 & Datar & 15 & 160 & $\begin{array}{l}\text { Zona Buffer } \\
\text { Konservasi }\end{array}$ \\
Area Pasif & 120 & Non Pohon & 25 & Landai & 30 & 175 & $\begin{array}{l}\text { Zna Buffer } \\
\text { Konservasi }\end{array}$ \\
Area Profan & 60 & Pohon & 50 & Sangat Curam & 75 & 185 & $\begin{array}{l}\text { Zona Buffer } \\
\text { Konservasi }\end{array}$ \\
Area Pasif & 120 & Pohon & 50 & Datar & 15 & 185 & $\begin{array}{l}\text { Zona Buffer } \\
\text { Konservasi }\end{array}$ \\
Area Pasif & 120 & Non Pohon & 25 & Agak Curam & 45 & 190 & $\begin{array}{l}\text { Zona Buffer } \\
\text { Konservasi }\end{array}$ \\
Area Pasif & 120 & Pohon & 50 & Landai & 30 & 200 & $\begin{array}{l}\text { Zona Buffer } \\
\text { Konservasi }\end{array}$ \\
Area Pasif & 120 & Pohon & 50 & Agak Curam & 45 & 215 & $\begin{array}{l}\text { Zona Buffer } \\
\text { Konservasi }\end{array}$ \\
Area Pasif & 120 & Non Pohon & 25 & Sangat Curam & 75 & 220 & $\begin{array}{l}\text { Zona Buffer } \\
\text { Konservasi }\end{array}$ \\
& & & & & & &
\end{tabular}




\begin{tabular}{llllllll}
\hline $\begin{array}{l}\text { Aktivitas } \\
\text { Sosial Budaya }\end{array}$ & $\begin{array}{l}\text { Total } \\
\text { Skor }\end{array}$ & Vegetasi & $\begin{array}{l}\text { Total } \\
\text { Skor }\end{array}$ & $\begin{array}{l}\text { Kemiringan } \\
\text { Lahan }\end{array}$ & $\begin{array}{l}\text { Total } \\
\text { Skor }\end{array}$ & $\begin{array}{l}\text { Jumlah } \\
\text { Total } \\
\text { Skor }\end{array}$ & Zona \\
\hline Area Buffer & 180 & Non Pohon & 25 & Datar & 15 & 220 & $\begin{array}{l}\text { Zona Buffer } \\
\text { Konservasi }\end{array}$ \\
Area Pasif & 120 & Pohon & 50 & Sangat Curam & 75 & 245 & $\begin{array}{l}\text { Zona Buffer } \\
\text { Konservasi }\end{array}$ \\
Area Buffer & 180 & Pohon & 50 & Datar & 15 & 245 & $\begin{array}{l}\text { Zona Buffer } \\
\text { Konservasi } \\
\text { Sakral }\end{array}$ \\
Area Sakral & 240 & Non Pohon & 25 & Datar & 15 & 280 & (5) \\
\hline
\end{tabular}

Sumber: Data Atribut Overlay peta aktivitas sosial budaya, vegetasi, dan kemiringan lahan pada GIS, 2020

Skor tertinggi 250 - 280, yaitu digunakan untuk zona sakral, dimana zona tersebut tidak boleh dikembangkan selain untuk kepentingan aktivitas agama. Zona buffer konservasi berdasarkan total skor yaitu mendapatkan nilai 160 - 245 zona ini difungsikan untuk area peralihan dari aktivitas sakral dengan aktivitas yang profan intensif dan fungsi konservasi untuk dominasi pohon dan kemiringan lahan yang curam. Total skor terendah 110 - 155 yaitu dimanfaatkan untuk zona profan yang difungsikan untuk aktivitas yang bernilai profan dengan intensitas yang tinggi seperti aktivitas dagang dan tempat parkir.

\subsection{Konsep dan Perencanaan Lanskap}

Konsep dasar perencanaan lanskap adalah menciptakan kawasan suci PDMJK yang selain berfungsi religi dan sosial budaya, juga bernilai keindahan dan ekologis yang tinggi. Konsep dasar disusun berdasarkan fungsi dan tujuan utama perencanaan dengan mempertimbangkan potensi dan solusi yang terdapat pada tapak. Konsep dasar ini kemudian dikembangkan ke konsep ruang, vegetasi, sirkulasi, dan fasilitasnya. Hasil akhir dari penelitian ini berupa rencana lanskap kawasan suci PDMJK.

\subsubsection{Konsep dan perencanaan tata ruang (zonasi)}

Konsep penataan ruang PDMJK diperoleh menggunakan scoring dan pembobotan pada data aktivitas sosial budaya, data vegetasi, dan data kemiringan lahan. Berdasaran hasil overlay pada data yang dianalisis menghasilkan tiga zona, yaitu zona sakral, zona buffer konservasi, zona profan.

Zona sakral tidak dikembangkan selain untuk aktivitas sakral. Zona ini terdiri dari area dalam pura. Area sakral yang difungsikan untuk aktivitas sakral seperti: sembahyang, prosesi sakral, dan kegiatan pra upacara seperti membuat upakaralbanten.

Zona buffer konservasi merupakan zona yang difungsikan untuk buffer atau area peralihan dari area yang bernilai profan intensif dengan area yang bernilai sakral. Pada area ini aktivitas yang direncanakan yaitu aktivitas manusia yang tidak terlalu intensif seperti mengobrol, berdiskusi, berisitirahat, atau menikmati suasana PDMJK. Zona ini akan dimanfaatkan sebagai taman untuk penunjang kawasan pura sebagai kawasan suci, selain itu juga dimanfaatkan sebagai area peralihan. Area taman ini direncanakan berdasarkan hasil rekomendasi dari masyarakat dimana di dalam kawasan PDMJK terdapat area untuk beristirahat, bersantai, melakukan diskusi setelah melakukan persembahyangan dan menunggu proses piodalan selesai, tepatnya pada saat piodalan di PDMJK. Area hutan yang difungsikan untuk konservasi terhadap tanaman yang bernilai upakara dan bernilai ekologi.

Zona profan merupakan zona yang dapat dikembangkan untuk aktivitas sosial yang bernilai intensif. Aktivitas yang direncanakan disini yaitu aktivitas dagang dan aktivitas parkir, aktivitas profan/sosial ini memiliki fungsi penting dalam keberlangsungan kegiatan yang ada di PDMJK. Zona ini terbagi dalam dua area yang direncanakan yaitu area dagang dan area parkir. Area kosong yang terdapat di zona ini dimanfaatkan untuk tamanisasi sebagai pendukung kawasan memiliki nilai keindahan. Berikut rencana tata ruang PDMJK dapat diamati pada Gambar 6. 


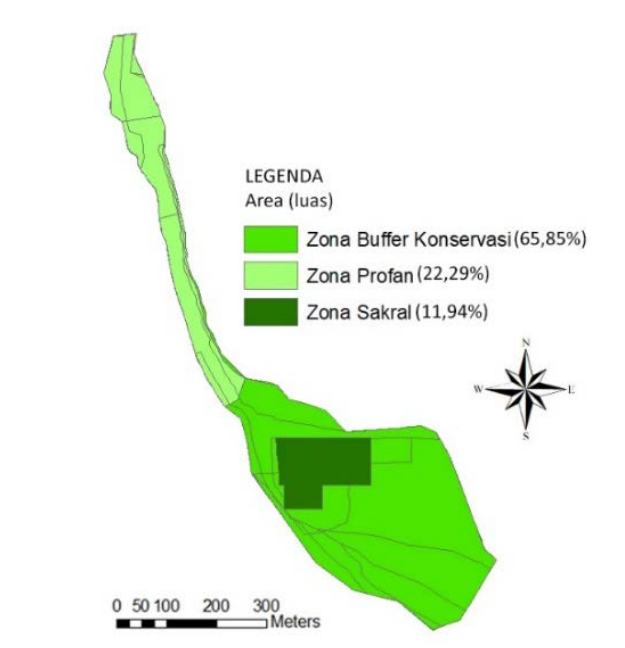

Gambar 6. Rencana Tata Ruang Kawasan PDMJK

\subsubsection{Konsep dan perencanaan Vegetasi}

Konsep penataan vegetasi di kawasan PDMJK berdasarkan nilai fungsional yaitu memiliki fungsi penting untuk pemenuhan bahan upakara atau sembahyang yang sering digunakan dalam ritual Agama Hindu Dan masyarakat Bali. Penerapan penataan vegetasi di PDMJK berdasarkan aspek filosofi sosial budaya masyarakat Bali yang mempertimbangkan nilai konservasi ekologis dan estetika, yang sesuai dengan perencanaan kawasan PDMJK sebagai tempat suci. Konsep vegetasi berdasarkan fungsi tanaman yang terdiri dari tanaman upakara dan tanaman konservasi. Konsep penataan vegetasi PDMJK terdapat pada Gambar 7. 1. Tanaman Upakara

Tanaman upakara adalah tanaman yang digunakan sebagai sarana upakara atau persembahyangan yang dibuat dari unsur buah, daun, bunga, dan air (Sardiana dan Dinata, 2010). Tanaman upakara ditata sesuai dengan zonasi/ tata ruang dari kawasan pura. Zona buffer konservasi menggunakan vegetasi atau tanaman upakara yang bernilai estetika untuk menambah keindahan dan kenyamanan khususnya di area taman kawasan PDMJK. Penataan tanaman upakara yang bernilai ekologis dipertahankan dan ditata kembali di area hutan. Selain sebagai penyuplai tanaman upakara, juga sebagai pencipta iklim mikro dan pelestarian habitat satwa di PDMJK. Penataan vegetasi di zona sakral yaitu tanaman upakara yang dapat dimanfaatkan langsung oleh masyarakat untuk sarana sembahyang. Tanaman upakara di zona profan yaitu bernilai estetika untuk mendukung kawasan PDMJK sebagai kawasan yang indah dan lestari.

2. Tanaman Konservasi

Tanaman konservasi yang direncanakan yaitu tanaman yang dapat menahan erosi dan tanaman yang berkarakter pohon di kawasan PDMJK. Perencanaan tanaman untuk penahan erosi yaitu tanaman yang berkarakter penutup tanah yang khusus ditanam untuk melindungi tanah dari ancaman kerusakan oleh erosi dan untuk memperbaiki kondisi tanah (Budiwati, 2015). Tanaman yang berkarakter pohon yang bernilai konservasi, yang dimanfaatkan untuk perlindungan habitat satwa di kawasan PDMJK dipertahankan. Tanaman yang memiliki fungsi sebagai pencipta iklim mikro juga dikonservasi untuk kontrol suhu di kawasan PDMJK. Tanaman eksisting yang berstrata pohon di kawasan PDMJK dipertahankan, baik yang terdapat pada zona buffer konservasi dan zona profan. Pada Zona buffer konservasi yaitu, tanaman berkarakter pohon yang bernilai konservasi, yang terdapat pada area hutan untuk dipertahankan sebagai nilai ekologis pembentuk iklim mikro dan pelestarian habitat satwa. Rencana vegetasi dapat diamati pada Gambar 7. 


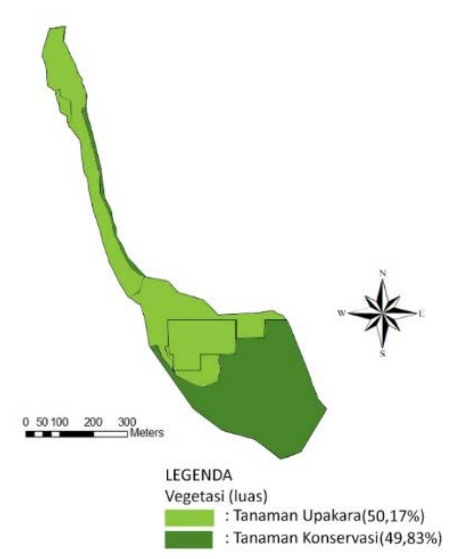

Gambar 7. Rencana Vegetasi

\subsubsection{Konsep dan perencanaan sirkulasi fasilitas}

Penataan sirkulasi pada kawasan PDMJK dibagi menjadi dua yaitu sirkulasi manusia dan sirkulasi kendaraan. Sirkulasi manusia menggunakan sirkulasi radial. Kawasan pura menjadi titik pusat dari sirkulasi kawasan PDMJK. Sirkulasi kendaraan menggunakan sirkulasi linear. Jalur sirkulasi manusia yaitu memiliki lebar $3 \mathrm{~m}-4 \mathrm{~m}$ dan 1,65 m. lebar 1,65 m yaitu jalur yang terdapat pada zona profan, berupa pedestrian yang berfungsi sebagai pembatas jalur pejalan kaki dan jalur kendaraan. Sirkulasi kendaraan di kawasan PDMJK yaitu sebatas di zona profan. Sirkulasi kendaraan memiliki panjang $280 \mathrm{~m}$ dengan lebar $4 \mathrm{~m}-5 \mathrm{~m}$. Material yang digunakan yaitu aspal.

Fasilitas yang ditambahkan pada kawasan PDMJK sesuai kebutuhan untuk kawasan berdasarkan dari hasil analisis dan sintesis yang dilakukan. Berdasarkan sintesis dari aspek biofisik yaitu perlunya kontrol akses masuk dari jalan soka. Kontrol akses masuk yaitu perlu adanya gapura candi yang berfungsi sebagai kontrol kawasan dengan tujuan aktivitas dari masyarakat dapat dikontrol baik dari segi waktu dan aktivitas. Perlu adanya fasilitas untuk memberikan kenyamanan beristirahat kepada pengunjung atau masyarakat saat mengunjungi pura. Berdasarkan analisis pada aktivitas sosial budaya, dimana perlu adanya tempat bagi masyarakat untuk duduk menikmati suasana pura dan sebagai tempat berinteraksi sembari menunggu prosesi adat di dalam pura. Oleh karena itu perlu adanya fasilitas pendukung yang disediakan yaitu bangku taman. Direncanakan juga fasilitas pedestrian untuk membatasi jalur pejalan kaki dengan jalur kendaraan.

\subsection{Site plan}

Pengembangan tata ruang yang direncanakan berdasarkan pertimbangan hasil sintesis sehingga penataan ruang sesuai dengan penataan aktivitas sosial budaya di kawasan pura yang merupakan kawasan suci. Pemilihan vegetasi sesuai dengan konsep budaya yang dibutuhkan sehingga bernilai guna bagi PDMJK serta memanfaatkan vegetasi eksisting yang bernilai ekologis. Menambahkan fasilitas yang sesuai dengan kebutuhan dari perencanaan sebuah kawasan suci yang berdasarkan aktivitas. Gambar site plan dapat diamati pada Gambar 8. 


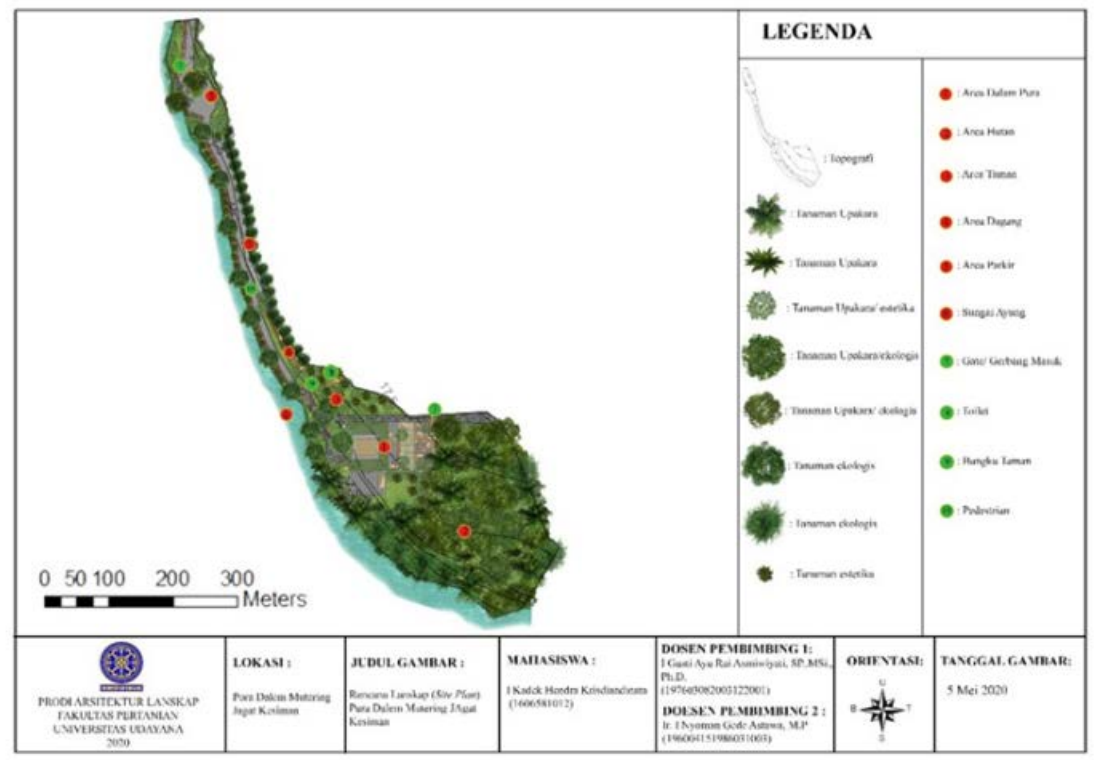

Gambar 8. Rencana Lanskap Kawasan suci PDMJK

\section{Simpulan dan saran \\ 4.1 Simpulan}

Penataan ruang dari kawasan ini berdasarkan hasil scoring dan pembobotan dari data biofisik dan sosial budaya. Pembobotan pada kedua aspek data menjadi konsep pengembangan ruang yang terbagi dalam tiga zona yaitu, zona sakral, zona buffer konservasi, zona profan. Penataan vegetasi dari kawasan pura yaitu berdasarkan kebutuhan sosial dan fungsi dari setiap area PDMJK. Penggunaan tanaman upakara dan tanaman konservasi menjadi alternatif penataan vegetasi. Tanaman upakara sebagai pemenuhan kebutuhan pengelola pura untuk kebutuhan sarana upakara dan tanaman konservasi sebagai pemenuhan nilai ekologis baik sebagai pelindung tanah dan pembentuk iklim mikro. Penataan sirkulasi yaitu terbagi dalam dua akses sirkulasi. Sirkulasi untuk akses kendaraan dan sirkulasi untuk akses manusia. Fasilitas direncanakan berdasarkan hasil sintesis sehingga perencanaan fasilitas sesuai dengan kebutuhan dalam kegiatan di kawasan PDMJK.

\subsection{Saran}

Perencanaan ini mempertimbangkan potensi dan kendala penting yang mempengaruhi PDMJK, oleh karena itu hasil perencanaan lanskap PDMJK dapat menjadi referensi alternatif penataan kawasan dalam mengembangkan kawasan suci yang sesuai dengan fungsi dari Pura Dalem Mutering Jagat Kesiman sebagai Pura Khayangan Tiga di Desa Adat Kesiman.

\section{Daftar Pustaka}

Ahern, J. (2014). Theories, methods and strategies for sustainable landscape planning. Department of Landscape Architecture and Regional Planning, University of Massachusetts, Amherst, MA 01003, USA.

Ardana, I. G. G. (1999). Pura Khayangan Tiga. Proyek Peningkatan Sarana Dan Prasarana Kehidupan Beragama Tersebar Di 9 (Sembilan) Daerah Tingkat II Tahun 1999/2000. Available online at: www.babadbali.com (diakses pada 4 januari 2021).

Budiwati, B. (2015). Tanaman Penutup Tanah Untuk Mencegah Erosi. Jurnal IImiah WUNY, 16(4), 1-7.

Fiantis, D. (2015). Morfologi Dan Klasifikasi Tanah. Lembaga Pengembangan Teknologi Informasi dan Komunikasi (LPTIK), Universitas Andalas.

Kusmawati, T. (2016). Kajian Kerusakan Tanah di Kecamatan Denpasar Timur Kota Denpasar. Program Studi Agroekoteknologi Fakultas Pertanian Universitas Udayana.

Raharja, G. M. (1993). Falsafah dan Konsep Ruang Tradisional Bali. Prodi Desain Interior ISI Denpasar.

Sardiana, I. K., \& K. K. Dinata. (2010). Studi Pemanfaatan Tanaman Pada Kegiatan Ritual (Upakara) Oleh Umat Hindu di Bali. Jurnal Bumi Lestari, 10, 123-127. 